\title{
PROFIL PEMECAHAN MASALAH MATEMATIKA KONTEKSTUAL SISWA SMP DITINJAU DARI KEPRIBADIAN MYER BRIGGS INDICATOR (MBTI)
}

\author{
Luthfia Laili Ayu Novitasari
}

Pendidikan Matematika, FMIPA, Universitas Negeri Surabaya, email: luthfia.17030174086@mhs.unesa.ac.id

\author{
Masriyah \\ Pendidikan Matematika, FMIPA, Universitas Negeri Surabaya, email: masriyah@unesa.ac.id
}

\begin{abstract}
Abstrak
Seseorang dengan kepribadian yang berbeda maka akan memiliki karakteristik kemampuan yang berbeda pula dalam menyelesaikan masalah matematika kontekstual. Terdapat banyak pengelompokan kepribadian, salah satunya kepribadian Myer Briggs Type Indicator (MBTI) yang membagi seseorang dalam 16 tipe. Tujuan penelitian ini untuk mendeskripsikan profil pemecahan masalah kontekstual siswa SMP dengan tipe kepribadian Introvert-Sensing-Thinking-Judging (ISTJ), Introvert-Sensing-Feeling-Judging (ISFJ), Introvert-iNtuition-Thinking-Judging (INTJ), dan Introvert-iNtuition-Feeling-Judging INFJ. Instrumen yang digunakan dalam penelitian ini adalah Tes Kepribadian MBTI, Tes Kemampuan Matematika (TKM), dan Tes Pemecahan Masalah Kontekstual. Subjek dalam penelitian ini adalah empat siswa kelas VIII dengan kepribadian ISTJ, ISFJ, INTJ, dan INFJ dengan kemampuan matematika yang setara. Empat subjek tersebut diberikan tes pemecahan masalah kontekstual untuk memperoleh data pemecahan masalah kontekstual siswa dengan kepribadian yang ditetapkan peneliti. Hasil tes pemecahan masalah matematika kontekstual dianalisis menggunakan langkah pemecahan masalah Polya. Pada tahap memahami masalah subjek ISTJ dan ISFJ memperoleh dan menyajikan data sesuai dengan apa yang dilihat oleh inderanya sedangkan subjek INTJ dan INFJ menghubungkan dengan informasi yang telah diketahui sebelumnya. Pada tahap membuat rencana pemecahan masalah subjek ISTJ dan INFJ melakukan analisis terlebih dahulu sebelum mengeksekusikannya sedangkan subjek ISFJ dan INFJ cenderung membayangkan dan merencanakan apa yang menurutnya benar. Pada tahap pelaksanaan rencana subjek ISTJ, ISFJ, INTJ, INFJ melaksanakan rencana penyelesaian yang telah disusun secara sistematis dan runtut. Subjek ISTJ dan INTJ memeriksa kembali dari langkah awal hingga akhir sedangkan subjek ISFJ dan INFJ hanya hitungan akhir. Keempat subjek tersebut dapat menyimpulkan jawaban akhir.
\end{abstract}

Kata Kunci: Pemecahan masalah, Masalah matematika kontekstual, Tipe kepribadian MBTI.

\begin{abstract}
Someone with different personalities will have different abilities in solving contextual math problems. One a lot of personality groupings, the example is Myer Briggs Type Indicator (MBTI) personalities which divides a person into 16 types. The aims of this study to describe the contextual problem-solving profile of the junior high school students with Introvert-Sensing-Thinking-Judging (ISTJ), Introvert-Sensing-Feeling-Judging (ISFJ), Introvert-iNtuition-Thinking-Judging (INTJ), and Introvert-iNtuition-Feeling-Judging INFJ. The instruments used in this study obtained from the MBTI Personality Test, Mathematics Ability Test (TKM), and Contextual Problem Solving Test. The subjects in this study comprised four students in class VIII that have ISTJ, ISFJ, INTJ, and INFJ personalities with similar math abilities. The four subjects were given contextual problem-solving tests to collect the data on students' contextual problem solving with the personality defined by the researcher. The results of the contextual math problem-solving test were analyzed using Polya's problem-solving steps. At the stage of understanding the problem, the ISTJ and ISFJ subject collected and showed the data according to what they saw by their senses, while the INTJ and INFJ subjects were related to previously known information. At the stage of making a problem-solving plan, the ISTJ and INFJ subject were analyzed before executed it, while the ISFJ and INFJ subjects tend to imagined and planned what they thought were right. At the implementation stage of the ISTJ, ISFJ, INTJ, and INFJ subject, carry out the settlement plan that has been prepared systematically and coherently. ISTJ and INTJ subjects were checked again their answer from start to finish while the ISFJ and INFJ subjects only counted the end answer. The four subjects can concluded the final answer.
\end{abstract}

Keywords: Problem solving, Contextual mathematics problem, Personality type of MBTI. 


\section{PENDAHULUAN}

Perkembangan dunia era globalisasi pada abad 21 ini ditandai dengan berkembangnya teknologi informasi dan komunikasi dalam segala aspek kehidupan, termasuk aspek pendidikan. Wijaya, Sudjimat, \& Nyoto (2016) menyatakan bahwa abad ke-21 juga dikenal dengan masa pengetahuan (knowledge age), dimana dapat dipahami bahwa di era 21 ini segala sesuatu dalam memenuhi kebutuhan hidup dan sumber daya manusia akan berpedoman pada pengetahuan. Hal ini menegaskan bahwa pendidikan merupakan salah satu aspek yang paling penting guna menciptakan sumber daya manusia yang berkualitas.

Matematika merupakan salah satu mata pelajaran yang memiliki peran penting dalam dunia pendidikan, hal tersebut dapat dilihat pada realita bahwa sejak kecil matematika sudah diajarkan pada setiap individu. Selain itu, matematika sebagai salah satu mata pelajaran wajib yang diajarkan mulai dari jenjang pendidikan dasar hingga jenjang perguruan tinggi (Umami, 2015). Perkembangan pendidikan menuntut siswa untuk lebih mengembangkan keterampilan matematika, untuk itu salah satu usaha pemerintah dalam mengembangkannya adalah dengan mengadaptasi konsep pembelajaran abad 21, salah satunya adalah $21^{\text {st }}$ Century Skills dalam bidang studi matematika. Pembelajaran abad 21 merupakan pembelajaran yang meleburkan kemampuan literasi, kecakapan pengetahuan, ketrampilan dan sikap, serta penguasaan terhadap teknologi. Menurut Nahdi (2019) bahwa setiap orang yang hidup di abad 21 ini, setidaknya harus memiliki 4 keterampilan salah satunya keterampilan berpikir kritis, dimana untuk mengembangkan keterampilan ini siswa harus sering diberikan permasalahan yang menuntut siswa agar dapat menyelesaikan pemecahan masalah tersebut.

Lampiran permendikbud Nomor 58 tahun 2014 tentang kurikulum SMP menjelaskan bahwa pemecahan masalah menjadi suatu hal yang paling penting dalam matematika. Dalam pemecahan masalah matematika dibutuhkan pemahaman konsep matematika yang mencakup kompetensi keterkaitan antar konsep dan penggunaan konsep ataupun algoritma (Subchan, winarni, Mufid, Fahim, \& Syaifudin, 2018). Dari uraian di atas maka dapat dikatakan sangat penting bagi peserta didik untuk dapat menyelesaikan pemecahan masalah matematika yang diberikan. Namun, apabila dilihat dari realita yang terjadi pada lingkungan sekolah peserta didik sering mengalami banyak kesulitan dalam memecahkan masalah. Hal tersebut didukung oleh hasil TIMSS (Trend in Internasional Mathematics and Science Survey) pada tahun 2015 yang menggambarkan bahwa peringkat Indonesia tergolong rendah. Indonesia menempati peringkat 44 dari 49 negara dengan rata-rata skor Indonesia adalah 397 sedangkan rata-rata skor
International adalah 500 ( (Hadi \& Novaliyosi, 2019). Dalam TIMMS terdapat 3 domain dalam karakteristik soal, yaitu mengetahui, mengaplikasikan, dan menalar, dimana ketiga domain tersebut diperlukan dalam pemecahan masalah matematika ( (Hadi \& Novaliyosi, 2019).

Rendahnya kemampuan pemecahan masalah matematika peserta didik berdasarkan hasil TIMSS tersebut diperkuat dengan realita yang ada di sekolah, bahwa peserta didik masih mengalami kesulitan dalam menyelesaikan soal pemecahan masalah matematika terutama dalam menyelesaikan dan memahami soal cerita yang bersubstansi kontekstual. Soal Kontekstual yang dimaksud dalam penelitian ini yaitu soal yang menggunakan konteks disekitar lingkungan siswa. Kriteria dalam menyusun soal kontekstual pada penelitian ini adalah dengan memilih konteks Dress-up, dimana dalam konteks ini bentuk soal diubah dengan bahasa cerita sehari-hari peserta didik (Suherman, 2015). Penelitian Tong \& Loc (2017) menjabarkan bahwa kesalahan yang dilakukan siswa dalam menyelesaikan masalah disebabkan oleh beberapa hal, diantaranya kecerobohan, subjektivitas, kesalahan penerapan solusi, dan adanya perhitungan yang tidak akurat.

Sebab itu penting untuk melatih siswa dengan latihan soal pemecahan masalah matematika terlebih masalah matematika kontekstual karena sangat berkaitan erat dengan kehidupan sehari-hari siswa. Sejalan dengan pendapat Herawaty \& Widada (2018) bahwa kemampuan kognitif siswa dalam memecahkan masalah menjadi lebih baik karena pengaruh model pembelajaran menggunakan contextual learning. Salah satu materi yang dapat dijadikan masalah matematika kontekstual adalah materi Sistem Persamaan Linear Dua Variabel, karena materi ini berkaitan erat dengan kegiatan sehari-hari siswa, selain itu berdasarkan hasil Ujian Nasional tahun 2019 secara nasional persentase peserta didik menjawab benar pada materi ini terutama pada soal kontekstual yang membutuhkan analisis dalam memahami masalah kurang dari 50\% (Puspendik, 2019).

Dalam menyelesaikan suatu masalah matematika, setiap individu memiliki cara yang berbeda dalam memecahkannya (Isroil, Budayasa, \& Masriyah, 2017). Sejalan dengan pendapat Pang (dalam Abdurrahman, 2010) menjelaskan bahwa seseorang dengan watak berbeda memiliki karakteristik kualitas matematika yang berbeda pula dalam banyak hal diantaranya menghubungkan antar konsep serta dalam pemecahan masalah yang berhubungan dengan kehidupan seharihari. Berdasarkan beberapa pendapat yang telah dijabarkan maka dapat dipahami bahwa adanya perbedaan dalam menyelesaikan masalah matematika kontekstual dapat disebabkan oleh kepribadian yang 
berbeda. Hal tersebut didukung oleh penelitian (Myszkowski, Storme, Davila, \& Lubart, 2015) yang membuktikan bahwa kepribadian secara signifikan memprediksi kreativitas pengelolaan data dalam menyelesaikan pemecahan masalah.

Kepribadian itu sendiri dapat meliputi pola pikir, perasaan dan tingkah laku dan merupakan karakter yang membedakan antara satu dengan yang lain. Beberapa ahli mengelompokkan kepribadian seseorang ke dalam tipe-tipe tertentu. Salah satunya tipe kepribadian dimensi Myer Briggs Type Indicator yang merumuskan secara luas tipe kepribadian berdasarkan pada teori Jung. Tipe kepribadian menurut Jung (1971), yaitu mempresentasikan cara orang lebih memilih untuk melihat dan menilai informasi yang ditemukan seharihari. Myers \& McCaulley ( dalam Martin, 1992) membagi tipe kepribadian menjadi empat sekala preferensi yang didasarkan pada: (1) dimensi pemerolehan energi (introvert-extrovert); (2) dimensi cara pemeroleh informasi (sensing-intuition); (3) dimensi cara pengambilan keputusan (thinking-feeling); dan (4) dimensi pola pelaksanaan tugas (judging perceiving). Dimensi tersebut sangat berkaitan erat dengan cara siswa dalam menyelesaikan pemecahan masalah kontekstual, saat siswa memahami masalah maka diperlukan cara dalam memperoleh informasi dapat dimungkinkan melalui indera (sensing) dan intuisi (intuition). Saat merencanakan pemecahan masalah dan pelaksanaan strategi dapat dimungkinkan melalui analisis pemikiran logis (thinking) atau perasaaan (feeling). Pada saat pemeriksaan kembali dapat dilihat bagaimana pola pelaksanaan tugas yang ditunjukkan oleh siswa dilakukan secara sistematis (judging) atau spontan (perceiving). Katharine Cook Briggs dan putrinya yang bernama Isabel Briggs Myers dalam (Barkai, 2009)) berdasarkan teori kepribadian dari Carl Gustav Jung membagi 16 macam tipe kepribadian yang berpusat pada empat sekala tersebut yaitu ISTJ, ISTP, ESTP, ESTJ, ISFJ, ISFP, ESFP, ESFJ, INFJ, INFP, ENFP, ENFJ, INTJ, INTP, ENTP, dan ENTJ. Dengan menyadari perbedaan kondisi pada masing- masing peserta didik seperti mengetahui tipe kepribadian siswa berdasarkan Myers Briggs Type Indicator, maka pengajar dapat memberikan model mengajar terbaik untuk masing-masing pribadi peserta didik. Jessee, O'Neill, \& Dosch (2006) mengungkapkan bahwa pembelajaran yang memperhatikan tipe kepribadian MBTI siswa merupakan salah satu cara untuk meningkatkan kemampuan dan ketertarikan siswa dalam belajar.

Beberapa penelitian yang relevan dengan penelitian ini telah dilakukan oleh Lutfiananda (2014) yang menyimpulkan bahwa subjek dengan kepribadian STJ dan NFJ dalam menyelesaikan pemecahan masalah open-ended pada tahap memahami masalah, menyusun strategi, melaksanakan strategi, dan memeriksa kembali terdapat perbedaan. Adapun penelitian selanjutnya yang relevan dengan penelitian ini adalah penelitian yang dilakukan oleh Anggreini \& Saputra (2020) yang berjudul "Profile of Skills Students in Resolving Problems Trigonometry Based on Personality Type Myer-Briggs" mengungkapkan bahwa sembilan tipe kepribadian MBTI memiliki ketrampilan matematika dalam menyelesaikan masalah dapat berbeda, dengan tipe ISTJ memiliki ketrampilan pemecahan masalah yang lebih tinggi dibanding yang lainnya karena dapat memenuhi semua indikator yang diberikan, tipe ENTJ, INTP, dan ISFJ memiliki ketrampilan pemecahan masalah yang cukup baik, tipe ESFJ, ESTP, INFJ, ISTP dan ESTJ memiliki ketrampilan pemecahan masalah matematika yang baik.

Dari penjabaran di atas, maka dapat dimungkinkan adanya perbedaan penyelesaian masalah matematika kontekstual pada siswa dengan beberapa kepribadian MBTI. Maka dari itu peneliti melakukan penelitian ini yang bertujuan untuk mendeskripsikan profil pemecahan masalah kontekstual siswa SMP tipe kepribadian ISTJ, ISFJ, INTJ dan INFJ. Peneliti memilih subjek tersebut karena kepribadian pada dimensi pemerolehan informasi dan pengambilan keputusan saling terkait serta merupakan kebalikan satu sama lain. Peneliti menjadikan dimensi pemerolehan energi dan pola pelaksanaan tugas sebagai variabel kontrol, dimana subjek dengan kepribadian introvert dan judging akan memperoleh energi dari dalam dirinya dan selalu bertumpu pada rencana yang sistematis (Mudrika, 2011).

\section{METODE}

Metode penelitian yang digunakan dalam penelitian ini yaitu deskriptif dengan pendekatan kualitatif. Sesuai dengan tujuan penelitian ini yaitu mendeskripsikan profil pemecahan masalah matematika kontekstual siswa SMP ditinjau dari empat kepribadian MBTI (Myerr Briggs Type Indicator) yaitu ISTJ (IntrovertSensing-Thinking-Judging), ISFJ (Introvert-SensingFeeling-Judging), INTJ (Introvert-Intuition-ThinkingJudging), INFJ (Introvert-Intuition-Feeling-Judging). Hal ini sesuai dengan pendapat Bogdan dan Taylor (dalam Moleong, 2012) metode kualitatif merujuk metode riset ini bersifat memberikan gambaran secara jelas suatu permasalahan sesuai dengan fakta di lapangan (lisan maupun tulisan) dari subjek yang diamati. Penelitian ini dilakukan pada siswa Sekolah Menengah Pertama (SMP) kelas VIII di Banyuwangi pada semester ganjil, tahun ajaran 2020/2021 secara online melalui google form yang masing-masing memiliki kepribadian ISTJ, ISFJ, INTJ, INFJ dan memiliki kemampuan matematis yang setara. 
Instrumen yang digunakan dalam penelitian ini adalah lembar tes kepribadian Myerr Briggs Type Indicator (MBTI) diadaptasi dari skala penilaian MBTI Mudrika (2011), yang merupakan alih bahasa dari sumber utama instrumen MBTI oleh Myer Briggs, lembar tes kemampuan matematis (TKM), lembar tes pemecahan masalah matematika kontekstual, dan pedoman wawancara. Pemilihan subjek penelitian dilakukan berdasarkan hasil tes kepribadian MBTI dan hasil tes kemampuan matematika. Tes tipe kepribadian MBTI terdiri dari 60 soal dengan perbandingan dimensi 15 soal untuk dimensi kepribadian introvert-extrovert, 15 soal untuk dimensi kepribadian sensing-intuition, 15 soal untuk kepribadian dimensi feeling-thinking, dan 15 soal untuk dimensi kepribadian judging-perceiving. Tes kemampuan matematis terdiri dari 10 soal uraian adaptasi dari buku dan kumpulan soal Ujian Nasional dengan waktu 75 menit. Tes pemecahan masalah kontekstual terdiri dari 4 soal uraian yang berkaitan dengan materi sistem persamaan linear dua variabel (SPLDV) dengan durasi pengerjaan 90 menit. Wawancara dilakukan setelah subjek mengerjakan lembar tes pemecahan masalah kontekstual, guna menggali informasi yang tidak tertulis dan mengetahui kejelasan lebih dalam mengenai hasil penyelesaian subjek dalam memecahkan masalah yang diberikan.

Analisis data terdapat empat macam yaitu, analisis data tes kepribadian MBTI, analisi data tes kemampuan matematika, analisis data pemecahan masalah kontekstual, dan wawancara. Analisis data tes kepribadian dilakukan dengan menggunakan kisi-kisi tes tipe kepribadian MBTI. Analisis data tes kemampuan matematika dilakukan dengan manggunakan pedoman penskoran lalu dilakukan pengelompokan skor siswa ke dalam tiga kategori yaitu tinggi, sedang, dan rendah. Pengelompokkan ditentukan berdasarkan KKM (Kriteria Ketuntasan Minimal) dengan interval sebagai berikut.

Tabel 1. 1 Kategori Kemampuan Matematika

\begin{tabular}{c|c}
\hline Kategori & Skor \\
\hline Tinggi & $86 \leq$ skor $\leq 100$ \\
\hline Sedang & $70 \leq$ skor $<86$ \\
\hline Rendah & Skor $<70$ \\
\hline
\end{tabular}

(Panduan Penilaian oleh Pendidik dan Satuan Pendidikan untuk Sekolah Menengah Pertama, 2017)

Analisis data tes pemecahan masalah kontekstual sistem persamaan linear dua variabel (SPLDV) dilakukan dengan berdasarkan indikator pemecahan masalah polya disajikan pada tabel berikut (Polya, 1973).

Tabel 1. 2 Indikator Pemecahan Masalah

\begin{tabular}{|c|c|c|c|}
\hline $\begin{array}{l}\text { Tahap } \\
\text { Pemecahan } \\
\text { Masalah Polya }\end{array}$ & Indikator Kemampuan Pemecahan Masalah & Kode & $\begin{array}{l}\text { Kepribadian } \\
\text { MBTI }\end{array}$ \\
\hline \multirow{3}{*}{$\begin{array}{l}\text { Memahami } \\
\text { masalah }\end{array}$} & Subjek dapat menentukan hal yang diketahui dalam soal & MM1 & \multirow{3}{*}{$\begin{array}{l}\text { Sensing vs } \\
\text { Intuition }\end{array}$} \\
\hline & Subjek dapat menentukan hal yang ditanyakan dalam soal & MM2 & \\
\hline & $\begin{array}{l}\text { Subjek dapat menentukan informasi yang belum diketahui/yang tidak } \\
\text { dibutuhkan sebagai syarat perlu penyelesaian masalah }\end{array}$ & MM3 & \\
\hline \multirow{2}{*}{$\begin{array}{l}\text { Membuat } \\
\text { rencana } \\
\text { pemecahan } \\
\text { masalah }\end{array}$} & $\begin{array}{l}\text { Subjek dapat menentukan strategi konsep SPLDV matematika yang } \\
\text { akan digunakan }\end{array}$ & RP1 & \multirow[b]{5}{*}{$\begin{array}{l}\text { Thinking vs } \\
\quad \text { Feeling }\end{array}$} \\
\hline & $\begin{array}{l}\text { Subjek dapat membuat keterkaitan atau hubungan dari data yang } \\
\text { diketahui dan yang tidak diketahui }\end{array}$ & RP2 & \\
\hline \multirow{3}{*}{$\begin{array}{l}\text { Melaksanakan } \\
\text { rencana } \\
\text { penyelesaian }\end{array}$} & Subjek dapat menyusun model matematika & PY1 & \\
\hline & $\begin{array}{l}\text { Subjek dapat menggunakan strategi/langkah yang tepat dalam } \\
\text { menyelesaikan masalah }\end{array}$ & PY2 & \\
\hline & $\begin{array}{l}\text { Subjek dapat melakukan perhitungan dengan menggunakan } \\
\text { konsep/cara/rumus yang sesuai }\end{array}$ & PY3 & \\
\hline \multirow{2}{*}{$\begin{array}{l}\text { Memeriksa } \\
\text { kembali }\end{array}$} & Subjek memeriksa kembali hasil pekerjaan & MK1 & \multirow{2}{*}{$\begin{array}{l}\text { Judging vs } \\
\text { Perceiving }\end{array}$} \\
\hline & Subjek dapat menyimpulkan hasil yang diperoleh & MK2 & \\
\hline
\end{tabular}


Analisis data hasil wawancara mengacu pada tahapan (Miles, Huberman, \& Saldana, 2014) yaitu tahap reduksi data, penyajian data, dan penarikan kesimpulan.

\section{HASIL DAN PEMBAHASAN}

Tes penggolongan kepribadian Myerr Briggs Type Indicator (MBTI) terlebih dahulu dilaksanakan pada dua kelas VIII SMP Negeri 1 Tegalsari semester ganjil tahun ajaran 2020/2021 untuk mendapatkan subjek penelitian. Tes penggolongan kepribadian Myerr Briggs Type Indicator (MBTI) berbasis online dengan cara mengisi kuisioner google form yang berisi 60 soal pilihan ganda, dengan dua pilihan jawaban. Kuisioner jawaban tes siswa dianalisis berdasarkan pedoman penilaian kepribadian oleh Myers Briggs.

Tes kemampuan matematis dilaksanakan setelah terpilih hasil tes kepribadian yang diinginkan peneliti. Tes ini dilakukan secara online yang terdiri atas 10 soal uraian. Jawaban siswa dianalisis berdasarkan pedoman penskoran tes kemampuan matematis. Hasil tes ini akan dipilih subjek dengan kemampuan matematika tinggi yang setara.

Data yang dipilih sesuai tabel 1.3, diperoleh 4 siswa dengan perbandingan persentase antar kepribadian yang
Subjek ISTJ menuliskan apa yang diketahui pada soal, hal tersebut ditunjukkan oleh kode MM1, selain itu subjek juga dapat menentukan apa yang ditanya pada soal ditunjukan pada tulisan subjek kode MM2 hal tersebut didukung oleh wawancara yang dilakukan peneliti terhadap subjek. Subjek ISTJ tidak menuliskan informasi apa yang belum diketahui/yang tidak diperlukan pada soal untuk menyelesaikan permasalahan tersebut namun subjek ISTJ dapat menentukannya melalui wawancara yang dilakukan peneliti. Transkip wawancara dijabarkan sebagai berikut.

Peneliti : Setelah kamu membaca soal, bisa disebutkan informasi apa saja yang kamu dapatkan?

Subjek ISTJ : Yang diketahui adalah uang Sasa 15.000 lalu dikenakan biaya parkir 2.000, Sasa membutuhkan 3 bolpoin dan 10 lembar kertas folio. Untuk yang ditanyakan itu apakah uang Sasa cukup untuk membeli alat tulis yang dibutuhkan Sasa.

Peneliti : Dari soal adakah informasi yang belum diketahui/ yang tidak digunakan?

Subjek ISTJ : Kalau untuk informasi yang tidak digunakan sepertinya tidak ada kak, karena semua informasi yang ada pada soal itu saya rasa dibutuhkan dalam menyelesaikan soal.

2) Analisis Subjek ISTJ Tahap Membuat Rencana

Tabel 1. 3 Persentase Kepribadian yang Terpilih

\begin{tabular}{|c|c|c|c|c|c|c|c|c|c|c|c|c|}
\hline \multirow{2}{*}{ No. } & \multirow{2}{*}{$\begin{array}{l}\text { Inisial } \\
\text { Nama }\end{array}$} & \multirow{2}{*}{$\begin{array}{l}\mathbf{J} \\
\mathbf{K}\end{array}$} & \multicolumn{8}{|c|}{ Persentase Kepribadian } & \multirow{2}{*}{ Kepribadian } & \multirow{2}{*}{$\begin{array}{l}\text { Skor } \\
\text { TKM }\end{array}$} \\
\hline & & & I & $\mathbf{E}$ & $\mathbf{S}$ & $\mathbf{N}$ & $\mathbf{T}$ & $\mathbf{F}$ & $\mathbf{J}$ & $\mathbf{P}$ & & \\
\hline 1. & FCO & $\mathrm{P}$ & 53 & 47 & 80 & 20 & 13 & 87 & 73 & 27 & ISFJ & 89 (Tinggi) \\
\hline 2. & DRW & $\mathrm{L}$ & 53 & 47 & 67 & 33 & 73 & 27 & 60 & 40 & ISTJ & 86 (Tinggi) \\
\hline 3. & NID & $P$ & 73 & 27 & 80 & 20 & 87 & 13 & 67 & 33 & ISTJ & 91 (Tinggi) \\
\hline 4. & CAS & $\mathrm{P}$ & 53 & 47 & 33 & 67 & 47 & 53 & 53 & 47 & INFJ & 87 (Tinggi) \\
\hline 5. & FNQA & $P$ & 60 & 40 & 27 & 73 & 80 & 20 & 73 & 27 & INTJ & 90 (Tinggi) \\
\hline 6. & HPA & $\mathrm{P}$ & 73 & 27 & 20 & 80 & 27 & 73 & 80 & 20 & INFJ & 89 (Tinggi) \\
\hline
\end{tabular}

hampir setara, dan kemempuan matematika tinggi yang setara. Siswa tersebut menjadi subjek penelitian untuk dilakukan tes selanjutnya yaitu tes pemecahan masalah matematika kontekstual. Untuk mengetahui hasil yang akurat dari tes pemecahan masalah kontekstual, maka dilakukan wawancara guna mengungkap hasil yang tidak tertulis dalam lembar jawaban subjek.

Data dan Analisis Siswa Berkepribadian ISTJ (introvert-sensing-thinking-judging) dalam Menyelesaikan Masalah Matematika Kontekstual.

1) Analisis Subjek ISTJ Tahap Memahami Masalah Gambar 3.1 Jawaban Subjek ISTJ Tahap Memahami Masalah Nomor 1

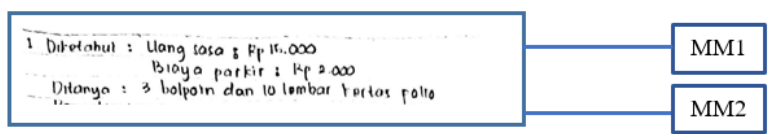

Pemecahan Masalah

Dalam tahap menyusun strategi, subjek ISTJ mencari harga barang yang belum diketahui melalui slip harga yang tersedia. Subjek ISTJ menyusun strategi dengan menganalisis terlebih dahulu terkait apa yang didapatkan pada soal dan data yang tersedia. Setelah menemukan harga dari barang yang tertera pada slip, subjek ISTJ mencari harga satu bolpoin dan satu lembar kertas folio menggunakan konsep SLDV dengan metode campuran (eliminasi dan substitusi). Langkah selanjutnya dengan mensubstitusikan hasil yang didapat pada ketentuan yang ditanyakan. Hal tersebut diketahui melalui wawancara yang dilakukan peneliti sebagai berikut.

Peneliti : Setelah mengetahui apa yang diketahui dan apa yang ditanya pada soal, apa yang kamu lakukan selanjutnya? 
Subjek ISTJ : Jadi saya mengamati terlebih dahulu, dan memikirkan apa yang harus saya lakukan. Saya lihat dulu slip harga yang diberikan, lalu saya hitung sisa uangnya untuk mengetahui berapa untuk persamaannya kak. Terus kalau sudah ketemu, dijadikan SPLDV kak saya menggunakan cara eliminasi lalu substitusi. Trus nanti bakal kelihatan hasilnya kak.

Peneliti : Apakah ada keterkaitan antara informasi yang diketahui dan yang tidak diketahui?

Subjek ISTJ : Ada kak, kan disediakan slip nih. Nah pada slip 1 maupun slip 2 itu akan didapatkan bentuk persamaannya kak. Nah dari situ nanti saya bisa melanjutkan dengan SPLDV.

3) Analisis Subjek ISTJ Tahap Melaksanakan Rencana Penyelesaian

Gambar 3.2 Jawaban Subjek ISTJ Tahap Melaksanakan Renana Penyelesaian Nomor 1

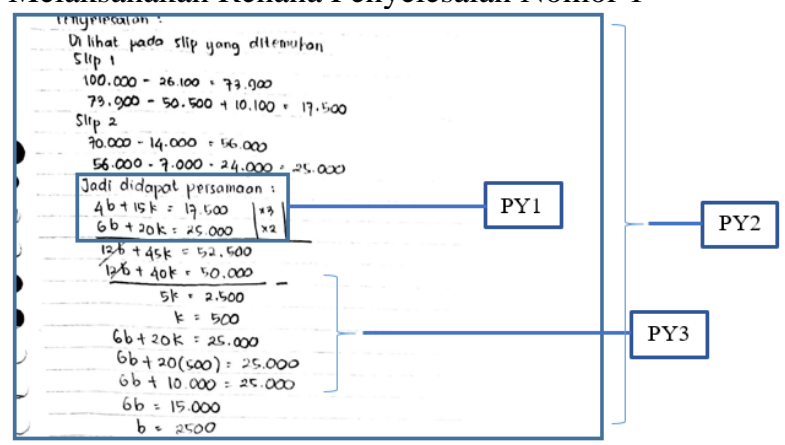

Berdasarkan gambar di atas pada kode PY1 subjek ISTJ dapat membentuk model matematika. Pada kode PY2 dapat dilihat bahwa subjek ISTJ dapat menggunakan strategi/langkah yang tepat dalam menyelesaikan masalah yang diberikan yaitu menggunakan metode eliminasi dan substitusi. Hal tersebut didukung oleh wawancara yang dilakukan peneliti kepada subjek. Subjek ISTJ juga dapat melakukan perhitungan yang sesuai dengan menggunakan metode eliminasi dan substitusi dalam soal permasalahan tersebut yang ditunjukan pada gambar kode PY3. hal tersebut didukung oleh hasil wawancara terhadap subjek. Berikut hasil transkip wawancara.

Peneliti : Tolong jelaskan langkah kamu mengerjakan dek. Subjek ISTJ : Jadi fungsinya slip kan untuk membentuk persamaan linearnya dn harganya, jadi saya hitung harga di slip tersebut dengan mengurangkan jumlah yang dibayar dengan kembalian lalu dikurangi lagi dengan harga yang tertera pada slip. Saya memisalkan b itu untuk bolpoin dan k itu untuk kertas folio. Nah setelah itu diselesaikan menggunakan eliminasi, nah ketemu kak b sama dengan 2.500 , setelah itu memakai substitusi lalu ketemu $\mathrm{k}$ sama dengan 500. Lalu yang ditanya apakah uang Sasa cukup membeli 3 bolpoin dan 10 lembar, jadi dimasukkan kak yang 2.500 dan 500 tadi. Setelah dimasukkan ketemu hasilnya 12.500 lalu uang Sasa yang 15.000 dikurangi 2.500 dikurangi lagi 2.000 dan hasilnya sisa 500 .
4) Analisis Subjek ISTJ Tahap Memeriksa Kembali Gambar 3.3 Jawaban Subjek ISTJ Tahap Memeriksa kembali Nomor 1

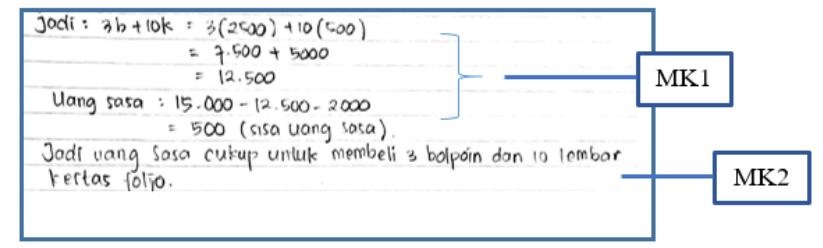

Berdasarkan gambar di atas dengan kode MK1 dapat dilihat subjek ISTJ memeriksa kembali hasil pekerjaan yang telah selesai dihitung. Hal tersebut diperkuat dengan hasil wawancara yang dilakukan peneliti terhadap subjek ISTJ. Subjek ISTJ dapat menyimpulkan hasil yang diperoleh dari permasalahan yang diberikan ditunjukkan pada gambar dengan kode MK2 didukung oleh hasil wawancara terhadap subjek tersebut. Transkip wawancara terhadap subjek ISTJ ditunjukkan sebagai berikut.

Peneliti: Apakah kamu memeriksa kembali penyelesaian pemecahan masalah yang kamu lakukan?

Subjek ISTJ : Iya, saya memeriksa kembali kak langkah saya dan hasil akhir hitungan saya.

Peneliti: Lalu kesimpulan apa yang bisa kamu buat setelah mengetahui jawabannya.

Subjek ISTJ : Setelah dihitung dengan mengurangi jumlah yang diperlukan dan uang parkir, uang sasa tersisa 500 jadi uang sasa cukup kak.

Data dan Analisis Siswa Berkepribadian ISFJ (introvert-sensing-feeling-judging) dalam Menyelesaikan Masalah Matematika Kontekstual

1) Analisis Subjek ISFJ Tahap Memahami Masalah

Gambar 3.4 Jawaban Subjek ISFJ Tahap Memahami Masalah Nomor 1

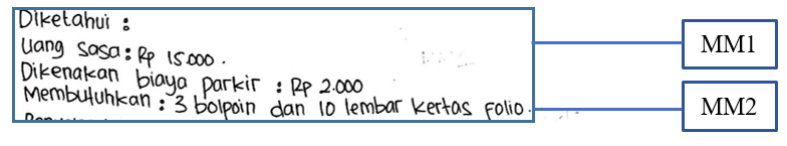

Berdasarkan gambar di atas subjek ISFJ menuliskan apa yang diketahui pada soal, hal tersebut ditunjukkan oleh kode MM1, selain itu subjek juga dapat menentukan apa yang ditanya pada soal ditunjukan pada tulisan subjek kode MM2 hal tersebut didukung oleh wawancara yang dilakukan peneliti terhadap subjek. Subjek ISFJ tidak menuliskan informasi apa yang belum diketahui/yang tidak diperlukan pada soal untuk menyelesaikan permasalahan tersebut namun subjek ISFJ dapat menentukannya melalui wawancara yang dilakukan peneliti. Transkip wawancara dijabarkan sebagai berikut.

Peneliti : Setelah kamu membaca soal, bisa disebutkan informasi apa saja yang kamu dapatkan?

Subjek ISFJ : Yang diketahui adalah uang Sasa 15.000 lalu dikenakan biaya parkir 2.000, Sasa membutuhkan 3 bolpoin dan 10 lembar kertas folio. Untuk yang ditanyakan itu apakah uang Sasa cukup untuk membeli alat tulis yang dibutuhkan Sasa.

Peneliti : Dari soal adakah informasi yang belum diketahui/ yang tidak digunakan? 
Subjek ISFJ : Ada kak, emm yang belum diketahui adalah berapa harga 1 bolpoin dan 1 lembar kertas folio. Lalu, kalau untuk informasi yang tidak digunakan sepertinya tidak ada kak, karena semua informasi yang ada pada soal itu saya rasa dibutuhkan dalam menyelesaikan soal.

2) Analisis Subjek ISFJ Tahap Membuat Rencana

Pemecahan Masalah

Dalam tahap menyusun strategi, subjek ISFJ mencari harga barang yang belum diketahui melalui slip harga yang tersedia. Subjek ISFJ menyusun strategi dari apa yang terlihat pada soal dengan membayangkan bagaimana langkah selanjutnya. Setelah menemukan harga dari barang yang tertera pada slip, subjek ISFJ mencari harga satu bolpoin dan satu lembar kertas folio menggunakan konsep SLDV dengan metode campuran (eliminasi dan substitusi). Langkah selanjutnya dengan mensubstitusikan hasil yang didapat pada ketentuan yang ditanyakan lalu menghubungkan dengan hal yang diketahui pada soal yaitu biaya parkir. Hal tersebut diketahui melalui wawancara yang dilakukan peneliti sebagai berikut.

Peneliti : Setelah mengetahui apa yang diketahui dan apa yang ditanya pada soal, apa yang kamu lakukan selanjutnya?

Subjek ISFJ : Saya menyusun rencana dan strategi kak, jadi saya membayangkan bagaimana cara saya menyelesaikannya. Jadi awalnya saya lihat dulu slip harga yang diberikan, nah dari situ nanti dihitung harganya berapa. Terus kalau sudah ketemu, dijadikan SPLDV kak lalu dicari masing-masingnya, setelah itu baru nanti tahu hasilnya.

Peneliti : Apakah ada keterkaitan antara informasi yang diketahui dan yang tidak diketahui?

Subjek ISFJ : Hmm saya rasa keterkaitannya ada pada slip itu sih kak, jadi kan kalau SPLDV selalu ada persamaannya, nah pada soal itu masih belum diketahui hasil persamaannya. Nah untuk mencari itu ya lewat slip yang diberikan tadi.

3) Analisis Subjek ISFJ Tahap Melaksanakan Rencana Penyelesaian

Gambar 3.5 Jawaban Subjek ISFJ Tahap Melaksanakan Rencana Penyelesaian

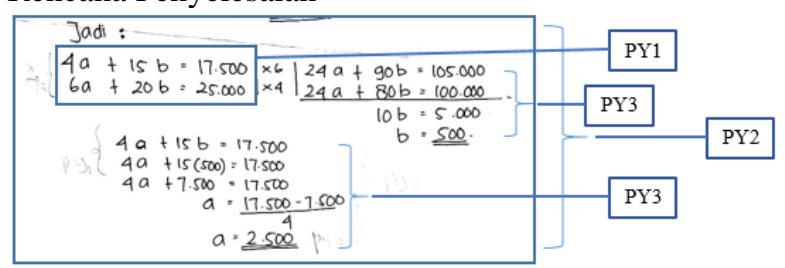

Berdasarkan gambar di atas pada kode PY1 subjek ISFJ dapat membentuk model matematika. Pada kode PY2 dapat dilihat bahwa subjek ISFJ dapat menggunakan strategi/langkah yang tepat dalam menyelesaikan masalah yang diberikan yaitu menggunakan metode eliminasi dan substitusi. Hal tersebut didukung oleh wawancara yang dilakukan peneliti kepada subjek. Subjek ISFJ juga dapat melakukan perhitungan yang sesuai dengan menggunakan metode eliminasi dan substitusi sehingga ditemukan hasil informasi yang belum diketahui dalam soal permasalahan tersebut yang ditunjukan pada gambar kode PY3. hal tersebut didukung oleh hasil wawancara terhadap subjek. Berikut hasil transkip wawancara.

Peneliti: Tolong jelaskan langkah kamu mengerjakan dek

Subjek ISFJ : Jadi setelah diketahui harga untuk memperoleh persamaannya dibentuk model persamaannya kak, nah saya memisalkan a itu untuk bolpoin dan b itu untuk kertas. Nah setelah itu diselesaikan menggunakan eliminasi, nah ketemu kak a sama dengan 2.500, setelah itu memakai substitusi lalu ketemu b sama dengan 500. Kan yang ditanya apakah uang Sasa cukup membeli 3 bolpoin dan 10 lembar, jadi dimasukkan kak yang 2.500 dan 500 tadi. Setelah dimasukkan ketemu hasilnya 12.500 lalu saya tambahkan dengan 2.000 uang parkir lalu ketemu kak biayanya 14.500 .

4) Analisis Subjek ISFJ Tahap Memeriksa Kembali

Gambar 3.6 Jawaban Subjek ISFJ Tahap Memeriksa Kembali

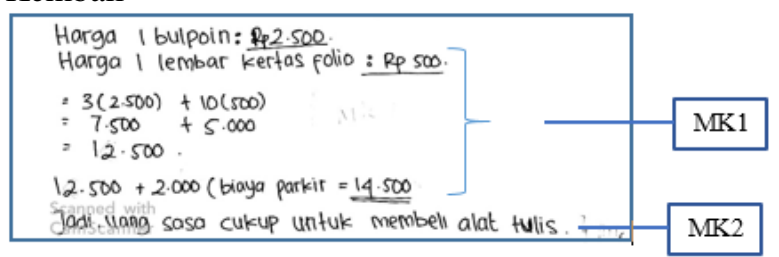

Berdasarkan gambar di atas dengan kode MK1 dapat dilihat subjek ISFJ memeriksa kembali hasil pekerjaan yang telah selesai dihitung. Hal tersebut diperkuat dengan hasil wawancara yang dilakukan peneliti terhadap subjek ISFJ. Subjek ISFJ dapat menyimpulkan hasil yang diperoleh dari permasalahan yang diberikan, namun hanya kesimpulan singkat ditunjukkan pada gambar dengan kode MK2 dan didukung oleh hasil wawancara terhadap subjek tersebut. Transkip wawancara terhadap subjek ISFJ ditunjukkan sebagai berikut.

Peneliti : Apakah kamu memeriksa kembali penyelesaian pemecahan masalah yang kamu lakukan?

Subjek ISFJ : Memeriksa sih kak, hitungannya saja karena saya rasa cara saya sudah benar, jadi saya Cuma memeriksa hitungan barangkali ada yang masih salah hitung.

Peneliti : Lalu kesimpulan apa yang bisa kamu buat setelah mengetahui jawabannya.

Subjek ISFJ : Uangnya Sasa cukup kak.

Data dan Analisis Siswa Berkepribadian INTJ (introvert-intuition-thinking-judging) dalam Menyelesaikan Masalah Matematika Kontekstual

1) Analisis Subjek INTJ Tahap Memahami Masalah Gambar 3.7 Jawaban Subjek INTJ Tahap Memahami Masalah

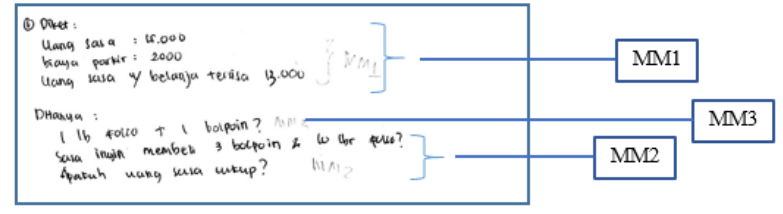


Berdasarkan gambar di atas subjek INTJ menuliskan apa yang diketahui pada soal, hal tersebut ditunjukkan oleh kode MM1, selain itu subjek juga dapat menentukan apa yang ditanya pada soal ditunjukan pada tulisan subjek kode MM2 hal tersebut didukung oleh wawancara yang dilakukan peneliti terhadap subjek. Subjek INTJ juga menuliskan informasi apa yang belum diketahui/yang tidak diperlukan pada soal untuk menyelesaikan permasalahan tersebut. Transkip wawancara dijabarkan sebagai berikut.

Peneliti: Setelah kamu membaca soal, bisa disebutkan informasi apa saja yang kamu dapatkan?

Subjek INTJ : Yang diketahui adalah uang Sasa 15.000 lalu dikenakan biaya parkir 2.000 jadi uang Sasa tersisa 13.000, Sasa membutuhkan 3 bolpoin dan 10 lembar kertas folio. Untuk yang ditanyakan itu apakah uang Sasa cukup untuk membeli alat tulis yang dibutuhkan Sasa.

Peneliti: Dari soal adakah informasi yang belum diketahui/ yang tidak digunakan?

Subjek INTJ : Ada kak, yang belum diketahui adalah berapa harga 1 bolpoin dan 1 lembar kertas folio. Lalu, kalau untuk informasi yang tidak digunakan tidak ada kak, karena pada slip yang diberikan itu juga memuat informasi yang dibtuhkan.

2) Analisis Subjek INTJ Tahap Membuat Rencana Pemecahan Masalah

Dalam tahap menyusun strategi, subjek INTJ mencari harga barang yang belum diketahui melalui slip harga yang tersedia. Subjek INTJ menyusun strategi dengan menganalisis terlebih dahulu adakah hubungan antar informasi yang tertera dengan yang dibutuhkan. Setelah menemukan harga dari barang yang tertera pada slip, subjek INTJ mencari harga satu bolpoin dan satu lembar kertas folio menggunakan konsep SLDV dengan metode campuran (eliminasi dan substitusi). Langkah selanjutnya dengan mensubstitusikan hasil yang didapat pada ketentuan yang ditanyakan. Hal tersebut diketahui melalui wawancara yang dilakukan peneliti sebagai berikut.

Peneliti : Setelah mengetahui apa yang diketahui dan apa yang ditanya pada soal, apa yang kamu lakukan selanjutnya?

Subjek INTJ : Saya menyusun rencana dan strategi kak, jadi saya mengamati terlebih dahulu, dan memikirkan apa yang benar-benar saya butuhkan untuk menyelesaikannya. Jadi saya lihat dulu slip harga yang diberikan, lalu saya hubungkan dengan apa yang belum diketahui. Terus kalau sudah ketemu, dijadikan SPLDV kak lalu dicari masing-masingnya, setelah itu baru nanti tahu hasilnya.

Peneliti : Apakah ada keterkaitan antara informasi yang diketahui dan yang tidak diketahui?

Subjek INTJ : Ada kak, pada slip 1 maupun slip 2 itu akan didapatkan bentuk persamaannya kak. Nah dari situ nanti saya bisa melanjutkan dengan SPLDV.

3) Analisis Subjek INTJ Tahap Melaksanakan Rencana Penyelesaian
Gambar 3.8 Jawaban Subjek INTJ Tahap Melaksanakan Rencana Penyelesaian Nomor 1

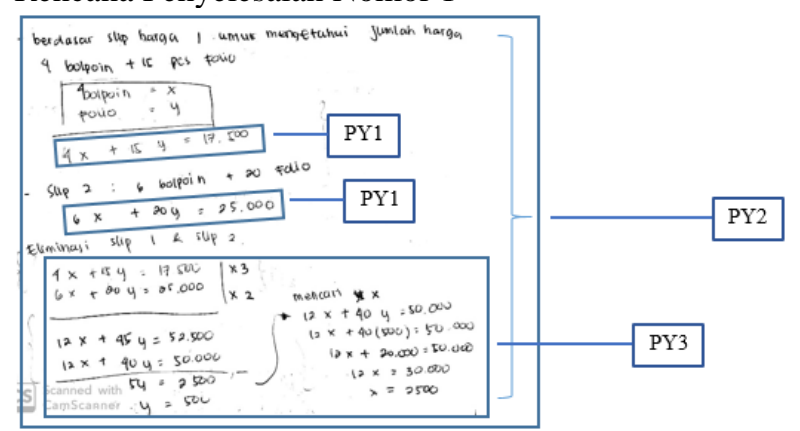

Berdasarkan gambar di atas pada kode PY1 subjek INTJ dapat membentuk model matematika. Pada kode PY2 dapat dilihat bahwa subjek INTJ dapat menggunakan strategi/langkah yang tepat dalam menyelesaikan masalah yang diberikan yaitu menggunakan metode eliminasi dan substitusi. Hal tersebut didukung oleh wawancara yang dilakukan peneliti kepada subjek. Subjek INTJ juga dapat melakukan perhitungan yang sesuai dengan menggunakan metode eliminasi dan substitusi sehingga ditemukan hasil informasi yang belum diketahui dalam soal permasalahan tersebut yang ditunjukan pada gambar kode PY3. hal tersebut didukung oleh hasil wawancara terhadap subjek. Berikut hasil transkip wawancara.

Peneliti: Tolong jelaskan langkah kamu mengerjakan dek

Subjek INTJ : Jadi kan dari slip akan dibentuk persamaannya dengan menghitung terlebih dahulu pada slip 1 dan slip 2 , nah saya memisalkan $\mathrm{x}$ itu untuk bolpoin dan y itu untuk kertas folio. Nah setelah itu diselesaikan menggunakan eliminasi, nah ketemu kak x sama dengan 2.500, setelah itu memakai substitusi lalu ketemu y sama dengan 500. Kan yang ditanya apakah uang Sasa cukup membeli 3 bolpoin dan 10 lembar, jadi dimasukkan kak yang 2.500 dan 500 tadi. Setelah dimasukkan ketemu hasilnya 12.500 lalu tinggal dilihat lagi, kan sisa uang Sasa yang awal tinggal 13.000. Jadi, uang Sasa cukup.

4) Analisis Subjek INTJ Tahap Memeriksa Kembali Gambar 3.9 Jawaban Subjek INTJ Tahap Memeriksa Kembali

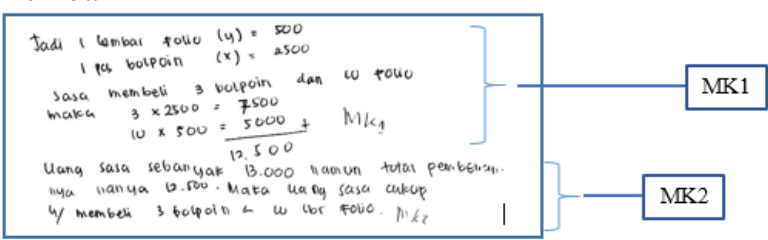

Berdasarkan gambar di atas dengan kode MK1 dapat dilihat subjek INTJ memeriksa kembali hasil pekerjaan yang telah selesai dihitung. Hal tersebut diperkuat dengan hasil wawancara yang dilakukan peneliti terhadap subjek INTJ. Subjek INTJ dapat menyimpulkan hasil yang diperoleh dari permasalahan yang diberikan ditunjukkan pada gambar dengan kode MK2 dengan rinci dan menghubungkan dengan pengetahuan awal yang dimiliki, didukung oleh hasil wawancara terhadap subjek tersebut. 
Transkip wawancara terhadap subjek INTJ ditunjukkan sebagai berikut.

Peneliti: Apakah kamu memeriksa kembali penyelesaian pemecahan masalah yang kamu lakukan?

Subjek INTJ : Memeriksa kak, saya memeriksa dari awal langkah begitu juga dengan perhitungannya, sampai pada hasil akhir.

Peneliti : Lalu kesimpulan apa yang bisa kamu buat setelah mengetahui jawabannya.

Subjek INTJ : Jadi ternyata 3 bolpoin dan 10 lembar kerta folio itu harganya hanya 12.500 , maka uang Sasa cukup untuk membeli karena uang Sasa sebesar 13.000.

Data dan Analisis Siswa Berkepribadian INFJ (introvert-intuition-feeling-judging) Menyelesaikan Masalah Matematika Kontekstual

1) Analisis Subjek INFJ Tahap Memahami Masalah

Gambar 3.10 Jawaban Subjek INFJ Tahap Memahami Masalah

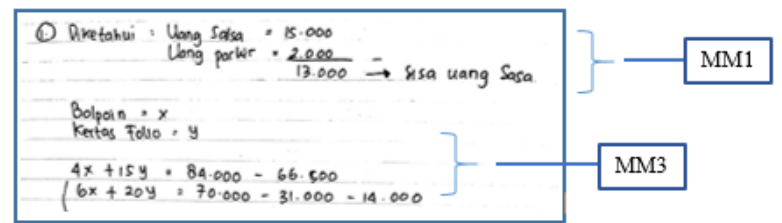

Berdasarkan gambar di atas subjek INFJ menuliskan apa yang diketahui pada soal, hal tersebut ditunjukkan oleh kode MM1, selain itu subjek juga dapat menentukan apa yang ditanya pada soal namun tidak dituliskan hal tersebut didukung oleh wawancara yang dilakukan peneliti terhadap subjek. Subjek INFJ juga menuliskan informasi apa yang belum diketahui/yang tidak diperlukan pada soal untuk menyelesaikan permasalahan tersebut. Transkip wawancara dijabarkan sebagai berikut.

Peneliti: Setelah kamu membaca soal, bisa disebutkan informasi apa saja yang kamu dapatkan?

Subjek INFJ : Yang diketahui adalah uang Sasa 15.000 lalu saya kurangi 2.000 untuk biaya parkir jadi uang Sasa tersisa 13.000, Sasa membutuhkan 3 bolpoin dan 10 lembar kertas folio. Untuk yang ditanyakan itu apakah uang Sasa cukup untuk membeli alat tulis tersebut.

Peneliti: Dari soal adakah informasi yang belum diketahui/ yang tidak digunakan?

Subjek INFJ : Ada kak, yang belum diketahui adalah berapa harga 1 bolpoin dan 1 lembar kertas folio. Lalu, kalau untuk informasi yang tidak digunakan tidak ada kak, karena pada slip yang diberikan itu juga memuat informasi yang dibutuhkan.

2) Analisis Subjek INFJ Tahap Membuat Rencana Pemecahan Masalah

Dalam tahap menyusun strategi, subjek INFJ mencari harga barang yang belum diketahui melalui slip harga yang tersedia. Subjek INFJ menyusun strategi dengan menghubungkan informasi yang tidak diketahui dan yang diketahui. Setelah menemukan harga dari barang yang tertera pada slip, subjek INFJ mencari harga satu bolpoin dan satu lembar kertas folio menggunakan konsep SLDV dengan metode campuran (eliminasi dan substitusi). Langkah selanjutnya dengan mensubstitusikan hasil yang didapat pada ketentuan yang ditanyakan lalu menghubungkan dengan uang yang tersisa. Hal tersebut diketahui melalui wawancara yang dilakukan peneliti sebagai berikut.

Peneliti : Setelah mengetahui apa yang diketahui dan apa yang ditanya pada soal, apa yang kamu lakukan selanjutnya?

Subjek INFJ : Saya menyusun rencana dan strategi kak, jadi saya membayangkan bagaimana cara saya menyelesaikannya. Jadi awalnya saya hitung dulu sisa uang Sasa setelah dikenakan prkir. Setelah itu saya melihat slip 1 dan slip 2 untuk menemukan persamaan yang bisa terbentuk. Lalu setelah dapat membentuk persamaannya diselesaikan menggunakan cara SPLDV dengan metode eliminasi dan substitusi sehingga akan diketahui hasilnya.

Peneliti : Apakah ada keterkaitan antara informasi yang diketahui dan yang tidak diketahui?

Subjek INFJ : Hmm saya rasa keterkaitannya ada pada slip itu sih kak, jadi kan kalau SPLDV selalu ada persamaannya, nah pada soal itu masih belum diketahui hasil persamaannya. Nah untuk mencari itu ya lewat slip yang diberikan tadi.

3) Analisis Subjek INFJ Tahap Melaksanakan Rencana Penyelesaian

Gambar 3.11 Jawaban Subjek INFJ Tahap Melaksanakan Rencana Penyelesaian

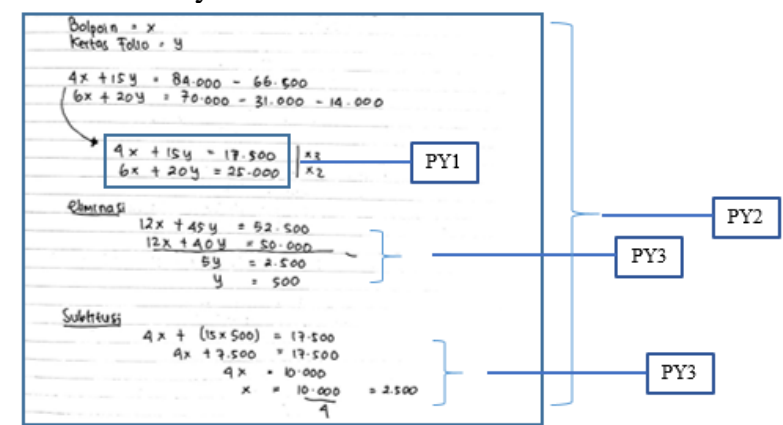

Berdasarkan gambar di atas pada kode PY1 subjek INFJ dapat membentuk model matematika. Pada kode PY2 dapat dilihat bahwa subjek INFJ dapat menggunakan strategi/langkah yang tepat dalam menyelesaikan masalah yang diberikan yaitu menggunakan metode eliminasi dan substitusi. Hal tersebut didukung oleh wawancara yang dilakukan peneliti kepada subjek. Subjek INFJ juga dapat melakukan perhitungan yang sesuai dengan menggunakan metode eliminasi dan substitusi sehingga ditemukan hasil informasi yang belum diketahui dalam soal permasalahan tersebut yang ditunjukan pada gambar kode PY3. hal tersebut didukung oleh hasil wawancara terhadap subjek. Berikut hasil transkip wawancara.

Peneliti : Tolong jelaskan langkah kamu mengerjakan dek

Subjek INFJ : Jadi setelah diketahui harga untuk memperoleh persamaannya dibentuk model persamaannya kak, nah saya memisalkan $\mathrm{x}$ itu untuk bolpoin dan y itu untuk kertas. Nah setelah itu diselesaikan menggunakan eliminasi, nah ketemu kak x sama dengan 2.500, setelah itu memakai substitusi lalu ketemu y sama dengan 500. Kan yang ditanya apakah uang Sasa cukup membeli 3 bolpoin dan 10 lembar, jadi dimasukkan kak yang 2.500 dan 500 tadi. Setelah dimasukkan ketemu hasilnya 12.500 lalu 
saya bandingkan dengan uang Sasa yang tersisa kan 13.000 , dan ternyata cukup.

4) Analisis Subjek INFJ Tahap Memeriksa Kembali Gambar 3.12 Jawaban Subjek INFJ Tahap Memeriksa Kembali

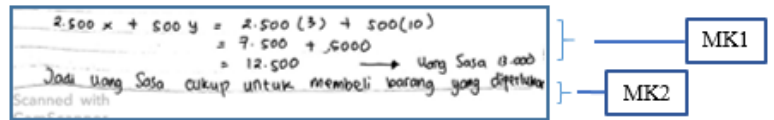

Berdasarkan gambar di atas pada kode MK1 dapat dilihat subjek INFJ memeriksa kembali hasil pekerjaan yang telah selesai dihitung. Hal tersebut diperkuat dengan hasil wawancara yang dilakukan peneliti terhadap subjek INFJ. Subjek INFJ dapat menyimpulkan hasil yang diperoleh dari permasalahan yang diberikan, dengan menghubungkannya dengan pengetahuan awal yang dimiliki ditunjukkan pada gambar dengan kode MK2 dan didukung oleh hasil wawancara terhadap subjek tersebut. Transkip wawancara terhadap subjek INFJ ditunjukkan sebagai berikut.

Peneliti : Apakah kamu memeriksa kembali penyelesaian pemecahan masalah yang kamu lakukan?

Subjek INFJ : Memeriksa sih kak, tapi tidak semua karena saya rasa cara saya sudah benar, jadi saya cuma memeriksa hitungan akhir saa barangkali ada yang masih salah hitung.

Peneliti : Lalu kesimpulan apa yang bisa kamu buat setelah mengetahui jawabannya.

Subjek INFJ : Kan awal uang Sasa yang telah dikurangi uang parkir ada 13.000, dan ternyata harga yang diperlukan Sasa hanya 12.500 jadi uang Sasa cukup kak.

\section{PEMBAHASAN}

Berdasarkan hasil dan analisis yang telah dilakukan, akan disajikan pembahasan profil pemecahan masalah matematika kontekstual siswa SMP ditinjau dari kepribadian myer briggs type indicator (MBTI) sebagai berikut.

1. Profil Pemecahan Masalah Matematika Kontektual Siswa SMP Ditinjau dari Kepribadian IntrovertSensing-Thinking-Judging (ISTJ)

a. Memahami Masalah

Subjek ISTJ memenuhi indikator memahami masalah karena dapat menuliskan apa yang diketahui dan apa yang ditanyakan pada soal. Selain itu subjek ISTJ dapat menentukan informasi yang belum diketahui/yang tidak dibutuhkan sebagai syarat penyelesaian masalah yang diberikan. Hal ini menunjukkan bagaimana cara subjek ISTJ dalam memperoleh suatu informasi yang didapatkan dari kelima indera sehingga data yang diperoleh berdasarkan fakta yang terdapat pada soal. Subjek ISTJ menyajikan data yang diperoleh sesuai apa yang terlihat. Hal tersebut sesuai dengan karakter dengan kepribadian sensing yang menegaskan bahwa dalam memperoleh informasi tipe sensing akan berdasarkan pada fakta yang terlihat dan data yang terekam oleh inderanya.

b. Membuat Rencana Pemecahan Masalah Pada langkah membuat rencana pemecahan masalah subjek ISTJ memenuhi indikator. Pada soal pemecahan masalah yang diberikan subjek ISTJ dapat menentukan dan menyusun strategi yang akan digunakan untuk menyelesaikan soal tersebut. Dalam menyusun rencana subjek ISTJ secara konsisten menggunakan konsep SPLDV dengan metode eliminasi dan substitusi. Subjek ISTJ menyusun strategi dengan menganalisis dari apa yang terlihat pada soal. Subjek ini dapat memprediksi dari langkah yang direncanakan, karena dalam merencanakannya subjek ini mengandalkan analisis dan logika. Sejalan dengan penelitan Handican \& Safitri (2017) yang menyatakan bahwa siswa dengan kepribadian thinking ialah siswa yang selalu menggunakan logika dan kekuatan analisis untuk mengambil keputusan.

c. Melaksanakan Rencana Penyelesaian

Pada langkah melaksanakan rencana penyelesaian subjek ISTJ telah memenuhi indikator. Pada soal pemecahan masalah pertama dan masalah kedua yang diberikan, subjek ISTJ dapat menuliskan model matematika dengan benar, sehingga strategi selanjutnya yang dilakukan subjek ISTJ dapat terlaksana secara sistematis sesuai dengan ketentuan rencana yang sudah disusun sebelumnya. Subjek ISFJ dapat melakukan perhitungan dengan benar menggunakan konsep dalam melaksanakan rancangan pemecahan masalah. Hal tersebut dapat dilihat karakter thinking dalam mengambil keputusan menggunakan analisis dan logika yang sesuai dalam soal. Selaras dengan penelitian (Handican \& Safitri, 2017) yang menyatakan bahwa siswa dengan kepribadian thinking ialah siswa yang selalu menggunakan logika dan kekuatan analisis untuk mengambil keputusan.

d. Memeriksa Kembali

Pada tahap memeriksa kembali subjek ISTJ memenuhi indikator dalam memeriksa kembali saat penyelesaian pemecahan masalah. Subjek ISTJ memeriksa kembali hasil pengerjaan secara keseluruhan dari awal pengerjaan dalam menyusun strategi sampai pada hasil akhir apakah memang benar sesuai atau tidak. Dalam menyimpulkan penyelesaian soal pemecahan masalah apa yang disimpulkan oleh subjek ISFJ sudah benar, ketika ditanya subjek ISFJ dapat 
menjelaskan rincian dengan terinci sesuai dengan analisis yang telah dilakukan subjek. Hal ini sejalan dengan penelitian (Jannah, 2016) yang menegaskan bahwa subjek dengan kepribadian STJ pada tahap verifikasi merupakan seorang yang aktif dan teliti karena cenderung menguji solusi yang didapat untuk mengetahui kesesuaiannya, sehingga subjek ini selalu memeriksa kembali penyelesaian masalah yang diberikan.

Berdasarkan pembahasan yang telah dibahas di atas sesuai dengan teori Briggs Myer (1985) bahwa seseorang dengan kepribadian ISTJ dalam memperoleh energi dengan menyimpannya dalam diri, ISTJ memperoleh informasi sesuai apa yang terlihat oleh inderanya dan sesuai fakta. Saat memutuskan suatu hal akan berdasarkan pada pemikiran logis dan anaisis yang dilakukan. Seseorang ISTJ mengerjakan sesuatu dengan runtut.

2. Profil Pemecahan Masalah Matematika Kontektual Siswa SMP Ditinjau dari Kepribadian IntrovertSensing-Feeling-Judging (ISFJ)

a. Memahami Masalah

Subjek ISFJ memenuhi indikator memahami masalah karena dapat menuliskan apa yang diketahui dan apa yang ditanyakan pada soal. Selain itu subjek ISFJ dapat menentukan informasi yang belum diketahui/yang tidak dibutuhkan sebagai syarat penyelesaian masalah yang diberikan. Hal ini menunjukan bagaimana cara subjek ISFJ dalam memperoleh suatu informasi yang didapatkan dari kelima indera sehingga data yang diperoleh berdasarkan fakta yang terdapat pada soal. Subjek ISFJ menyajikan data yang diperoleh sesuai apa yang terlihat. Hal tersebut sesuai karakter seseorang dengan kepribadian sensing dalam memperoleh informasi akan berdasarkan pada fakta yang terlihat dan data yang terekam oleh inderanya. Sejalan dengan penelitian Rohim \& Sari (2019) yang mengungkapkan bahwa subjek dengan kepribadian sensing hanya fokus pada apa yang didapat saja, dalam memahami masalah subjek sensing hanya mampu menerima dan memahami informasi yang tertera pada lembar soal.

b. Membuat Rencana Pemecahan Masalah Pada langkah membuat rencana pemecahan masalah subjek ISFJ memenuhi indikator. Pada soal pemecahan masalah yang diberikan subjek ISFJ dapat menentukan dan menyusun strategi yang akan digunakan untuk menyelesaikan soal tersebut. Dalam menyusun rencana subjek ISFJ secara konsisten menggunakan konsep SPLDV dengan metode eliminasi dan substitusi. Subjek ISFJ menyusun strategi dari apa yang terlihat pada soal dengan membayangkan bagaimana langkah selanjutnya. Subjek ini tidak dapat memberikan prediksi dari langkah yang direncanakan, karena dalam merencanakannya subjek ini hanya berdasarkan perasaan pribadi atau biasa disebut subjektif. Hal ini selaras dengan penelitian Fauzi \& Abidin (2019) yang menyebutkan bahwa subjek dengan karakter feeling dalam mengusulkan strategi masih belum bisa membuat prediksi dari langkah yang diusulkan.

c. Melaksanakan Rencana Penyelesaian

Pada langkah melaksanakan rencana penyelesaian subjek ISFJ memenuhi indikator. Pada soal pemecahan masalah pertama yang diberikan subjek ISFJ dapat menuliskan model matematika dari soal tersebut namun pada soal pemecahan masalah yang kedua masih belum benar sehingga mempengaruhi langkah berikutnya dalam menyelesaikannya. Subjek ISFJ dapat menggunakan strategi yang telah dirancang sebelumnya dengan benar pada soal pemecahan masalah yang pertama, namun untuk soal pemecahan masalah yang kedua subjek ISFJ kurang benar dalam melaksanakan rencana penyelesaian karena mengandalkan feeling dalam menyelesaikannya. Sehingga, untuk mencari apa yang dibutuhkan menggunakan coba-coba dan cara yang menurutnya benar. Hal tersebut sejalan dengan pendapat Jannah (2016) yang mengungkapkan bahwa siswa dengan kepibadian SFJ cenderung berpegang pada feeling bukan teori, dalam artian subjek ini dapat menemukan cara lain namun cara tersebut cenderung asal-asalan atau menggunakan cara sendiri. Namun, subjek ISFJ dapat melakukan perhitungan dengan menggunakan konsep/rumus yang sesuai. Hal tersebut menjelaskan, bahwa subjek ISFJ dapat melakukan perhitungan yang sesuai meskipun dalam melaksanakan rancangan penyelesaiannya masih subjektif/sesuai feeling pribadi.

d. Memeriksa Kembali

Subjek ISFJ memenuhi indikator dalam memeriksa kembali saat penyelesaian pemecahan masalah. Subjek ISFJ memeriksa kembali hasil pengerjaan bagian akhir namun tidak memeriksa secara keseluruhan karena telah merasa bahwa jawaban yang ditulis sudah benar. Dalam menyimpulkan penyelesaian soal 
pemecahan masalah apa yang disimpulkan oleh subjek ISFJ sudah benar, namun ketika ditanya mengenai penjelasan lebih mendalam terkait kesimpulan yang dibuat subjek ISFJ masih belum bisa menjelaskan secara rinci. Hal tersebut dapat dimengerti karena karakter feeling yang melekat pada subjek ini. Sesuai dengan pendapat Fauzi \& Abidin (2019) yang menyatakan pada indikator assesmen siswa dengan karakter feeling tidak dapat menunjukkan alasan tentang kesimpulan berdasarkan langkah penyelesaian yang dilakukan.

Berdasarkan pembahasan yang telah dibahas di atas sesuai dengan teori Briggs Myer (1985) bahwa seseorang dengan kepribadian ISFJ dalam memperoleh energi dengan menyimpannya dalam diri, ISFJ memperoleh informasi sesuai apa yang terlihat oleh inderanya dan sesuai fakta. Saat memutuskan suatu hal akan berdasarkan pada pandangan dan perasaan pribadi (subjektif). Seseorang ISFJ mengerjakan sesuatu dengan runtut.

3. Profil Pemecahan Masalah Matematika Kontektual Siswa SMP Ditinjau dari Kepribadian IntrovertiNtuition-Thinking-Judging (INTJ)

a. Memahami Masalah

Subjek INTJ memenuhi indikator memahami masalah karena dapat menuliskan apa yang diketahui dan apa yang ditanyakan pada soal. Selain itu subjek INTJ dapat menentukan informasi yang belum diketahui/yang tidak dibutuhkan sebagai syarat penyelesaian masalah yang diberikan melalui pola dan hubungan dari data yang diketahui. Hal ini menunjukan bagaimana cara subjek INTJ dalam memperoleh suatu informasi yang didapatkan menggunakan hubungan atau pola dari data yang diberikan. Hal tersebut sesuai dengan karakter dengan kepribadian intuition yang menegaskan bahwa dalam memperoleh informasi tipe intuition akan berdasarkan pada pola atau hubungan dari data yang dikumpulkan. Selaras dengan penelitian Abid (2018) yang menjabarkan bahwa subjek dengan tipe intuition dalam mengetahui informasi memiliki kemampuan untuk menghubungkan sesuatu yang dianggap memiliki hubunga dari apa yang didapat secara langsung atau melalui penciptaan pola dari informasi yang ada pada soal.

b. Membuat Rencana Pemecahan Masalah Dalam tahap menyusun strategi, subjek INTJ mencari informasi yang belum diketahui. Subjek INTJ menyusun strategi dengan menganalisis terlebih dahulu adakah hubungan antar informasi yang tertera dengan yang dibutuhkan. Setelah menemukan harga dari data yang tidak diketahui, subjek INTJ membuat bentuk matematika dari data tersebut. Dengan menggunakan konsep SLDV dengan metode campuran (eliminasi dan substitusi) maka akan didapatkan hasil. Dalam hal ini bisa dilihat bahwa subjek INTJ akan melakukan analisis terlebih dahulu dengan logika lalu menghubungkannya dengan konsep atau informasi yang telah didapatkan sebelumnya. Sejalan dengan penelitian Sofiani (2019) yang mengungkapkan bahwa subjek dengan kepribadian rational (INTJ) dalam mengidentifikasi masalah cenderung menggunakan logika, dan dalam merencanakan representasi pemecahan masalah dengan menghubungkan informasi yang ada pada representasi awal dengan representasi target.

c. Melaksanakan Rencana Penyelesaian

Pada langkah melaksanakan rencana penyelesaian subjek INTJ telah memenuhi indikator. Pada soal pemecahan masalah pertama subjek INTJ dapat menuliskan model matematika dengan benar, pada soal pemecahan masalah yang kedua subjek INTJ menuliskan dua model matematika namun untuk model matematika yang kedua subjek INTJ menuliskan dengan benar, sehingga strategi selanjutnya yang dilakukan subjek INTJ dapat terlaksana sesuai dengan ketentuan rencana yang sudah disusun sebelumnya. Subjek INTJ dapat melakukan perhitungan dengan benar karena menggunakan cara yang memudahkan dalam pengerjaannya menggunakan konsep dalam melaksanakan rancangan pemecahan masalah. Sejalan dengan penelitian Jannah (2016) yang menjelaskan bahwa siswa dengan tipe kepribadian NTJ lebih objektif dalam mengambil keputusan untuk menentukan solusi, karena berdasarkan alasan-alasan yang logis dan dapat menjalankan strategi dengan sistematis dan runtut.

d. Memeriksa Kembali

Pada tahap memeriksa kembali subjek INTJ memenuhi indikator dalam memeriksa kembali saat penyelesaian pemecahan masalah. Subjek INTJ memeriksa kembali hasil pengerjaan secara keseluruhan dari awal pengerjaan dalam menyusun strategi sampai pada hasil akhir apakah memang benar sesuai atau tidak. Dalam menyimpulkan penyelesaian soal pemecahan 
masalah apa yang disimpulkan oleh subjek INTJ sudah benar, karena dapat menghubungkannya dengan informasi data yang telah diketahui sebelumnya. Hal ini selaras dengan penelitian Setiyaningrum (2019) yang mengungkapkan bahwa subjek dengan kepribadian INTJ memiliki kecenderugan berpikir menggunakan pengertian dan menghubungkan dengan pengetahuan sebelumya, sehingga dalam membentuk sebuah kesimpulan akan cenderung tepat.

Berdasarkan pembahasan yang telah dibahas di atas sesuai dengan teori Briggs Myer (1985) bahwa seseorang dengan kepribadian INTJ dalam memperoleh energi dengan menyimpannya dalam diri, INTJ memperoleh informasi dengan menghubungkan apa yang pernah diketahui/dialami. Saat memutuskan suatu hal akan berdasarkan pada pikiran logis dan analisisnya. Seseorang ISFJ mengerjakan sesuatu dengan runtut.

4. Profil Pemecahan Masalah Matematika Kontektual Siswa SMP Ditinjau dari Kepribadian IntrovertiNtuition-Feeling-Judging (INFJ)

a. Memahami Masalah

Subjek INFJ telah memenuhi indikator memahami masalah karena dapat menuliskan apa yang diketahui namun tidak menuliskan apa yang ditanya. Selain itu subjek INFJ dapat menentukan informasi yang dibutuhkan sebagai syarat penyelesaian masalah yang diberikan. Selain itu subjek INFJ dapat menghubungkan informasi yang belum diketahui dan yang sudah diketahui sebagai syarat penyelesaian masalah yang diberikan. Hal ini menunjukan bagaimana cara subjek INFJ dalam memperoleh suatu informasi yang didapatkan menggunakan hubungan atau pola dari data yang diberikan. Hal tersebut sesuai dengan karakter dengan kepribadian intuition dimana kepribadian ini dalam memperoleh informasi akan mengaitkan dan menghubungkan dengan pola atau sesuatu yang pernah ada/dialami. Didukung oleh pendapat Rohim \& Sari (2019) yang menyatakan bahwa subjek dengan tipe sensing dapat memahami masalah dengan mendefinisikan apa yang diketahi pada soal. Subjek ini cenderung mampu mengaitkan topik soal dengan topik lain.

b. Membuat Rencana Pemecahan Masalah Subjek INFJ memenuhi indikator dalam membuat rencana. Dalam tahap menyusun strategi, subjek INFJ menyusun strategi dengan menghubungkan informasi yang tidak diketahui dan yang diketahui. Setelah menemukan apa yang didapatkan subjek ISFJ mengeksekusikannya menggunakan konsep SLDV dengan metode campuran (eliminasi dan substitusi). Langkah selanjutnya dengan mensubstitusikan hasil yang didapat pada ketentuan yang ditanyakan lalu menghubungkan dengan informasi yang telah dihubungkan. Sesuai dengan pendapat Setiyaningrum (2019) yang menyatakan bahwa subjek ENFJ dengan NFJ sebgai fokus dalam proses membentuk pendapat dalam rencana pemecahan cenderung menghubungkannya dengan pengetahuan yang telah sebelumnya dimiliki.

c. Melaksanakan Rencana Penyelesaian

Subjek INFJ telah memenuhi indikator melaksanakan rencana penyelesaian. Pada soal pemecahan masalah yang diberikan subjek INFJ dapat menuliskan model matematika secara tepat. Subjek INFJ dapat menggunakan strategi yang telah dirancang sebelumnya dengan benar pada soal pemecahan masalah yang diberikan. Subjek INFJ dapat melakukan perhitungan dengan menggunakan konsep/rumus yang sesuai. Dalam proses perhitungannya subjek INFJ menggunakan cara yang berbeda dari subjek lainnya. Namun, subjek INFJ tidak dapat menjelaskan secara logis mengenai proses perhitungan dalam melaksanakan rencana penyelesaian masalah karena bersandar pada feeling yang menjelaskan bahwa apa yang menurutnya benar maka itulah yang akan ditulis. Sejalan dengan pendapat Dardiri, Supratman, \& Ratnaningsih (2020) yang menegaskan bahwa peserta subjek dengan kepribadian feeling akan membuat keputusan berdasarkan kriteria subjektif dengan perasaannya sendiri.

d. Memeriksa Kembali

Pada tahap ini subjek INFJ telah memenuhi indikator. Subjek INFJ memeriksa kembali hasil yang didapatkan dengan ketentuan yang diberikan. Dalam menyimpulkan penyelesaian soal pemecahan masalah apa yang disimpulkan oleh subjek INFJ sudah benar, namun ketika ditanya mengenai penjelasan lebih mendalam terkait kesimpulan yang dibuat subjek INFJ hanya berupa gambaran singkat dan belum terinci. Selaras dengan penelitian Lutfiananda (2014) yang menyatakan bahwa subjek NFJ memeriksa kembali kesesuaian pelaksanaan strategi dengan melihat proses pemecahan masalah dengan ketentuan yang diberikan, 
namun siswa hanya menyampaikan gambaran singkat tanpa disertai rincian.

Berdasarkan pembahasan yang telah dibahas di atas sesuai dengan teori Briggs Myer (1985) bahwa seseorang dengan kepribadian INFJ dalam memperoleh energi dengan menyimpannya dalam diri, INFJ memperoleh informasi cenderung menghubungkan dengan apa yang pernah diketahui/dialami. Saat memutuskan suatu hal akan berdasarkan pada pandangan dan perasaan pribadi (subjektif). Seseorang INFJ mengerjakan sesuatu dengan runtut.

\section{PENUTUP}

\section{Simpulan}

Berdasarkan hasil data analisis dan pembahasan, maka dapat diambil simpulan sebagai berikut.

1. Profil Pemecahan Masalah Matematika Kontekstual Siswa SMP Ditinjau dari Kepribadian IntrovertSensing-Thinking-Judging (ISTJ).

Pada langkah memahami masalah, siswa ISTJ dapat memenuhi indikator memahami masalah. Cara siswa ISTJ dalam memperoleh suatu informasi untuk memahami masalah, berdasarkan fakta yang terdapat pada soal. Pada langkah membuat rencana pemecahan masalah siswa ISTJ menganalisis terlebih dahulu apa yang terdapat pada soal, sehingga dapat memprediksi bagaimana langkah yang harus dilakukan setelahnya. Siswa ISTJ menuliskan model matematika dengan benar, sehingga strategi selanjutnya yang dilakukan siswa ISTJ dapat terlaksana secara sistematis sesuai dengan ketentuan rencana yang sudah disusun sebelumnya. Siswa ISTJ memeriksa kembali hasil pengerjaan secara keseluruhan dari awal pengerjaan dalam menyusun strategi sampai pada hasil akhir. Dalam menyimpulkan penyelesaian soal pemecahan siswa ISTJ dapat menjelaskan rincian dengan terinci sesuai dengan analisis yang telah dilakukan subjek.

2. Profil Pemecahan Masalah Matematika Kontekstual Siswa SMP Ditinjau dari Kepribadian IntrovertSensing-Feeling-Judging (ISFJ).

Pada langkah memahami masalah siswa ISFJ dapat memenuhi indikator memahami masalah. Siswa ISFJ memperoleh informasi dari kelima indera sehingga data yang diperoleh berdasarkan fakta yang terdapat pada soal. Siswa ISFJ menyusun strategi dengan membayangkan bagaimana langkah selanjutnya. Siswa ISFJ ini tidak dapat memberikan prediksi dari langkah yang direncanakan, karena dalam merencanakannya, hanya berdasarkan perasaan pribadi atau biasa disebut subjektif. Dalam melaksanakan rencana penyelesaian karena mengandalkan feeling untuk mencari apa yang dibutuhkan siswa ISFJ menggunakan coba-coba dan cara yang menurutnya benar. Siswa ISFJ memeriksa kembali hasil pengerjaan bagian akhir namun tidak memeriksa secara keseluruhan karena telah merasa bahwa jawaban yang ditulis sudah benar. Dalam menyimpulkan penyelesaian soal pemecahan siswa ISFJ masih belum bisa menjelaskan secara rinci.

3. Profil Pemecahan Masalah Matematika Kontekstual Siswa SMP Ditinjau dari Kepribadian IntrovertiNtuition-Thinking-Judging (INTJ).

Pada langkah memahami masalah, siswa INTJ memenuhi indikator memahami masalah. Cara siswa INTJ dalam memperoleh suatu informasi yang didapatkan menggunakan hubungan atau pola dari data yang diberikan. Siswa INTJ menyusun strategi dengan melakukan analisis terlebih dahulu menggunakan logika lalu menghubungkannya dengan konsep atau informasi yang telah didapatkan sebelumnya. Pada langkah melaksanakan rencana penyelesaian strategi yang dilakukan siswa INTJ dapat terlaksana sesuai dengan ketentuan rencana yang sudah disusun sebelumnya. Siswa INTJ dapat melakukan perhitungan menggunakan cara yang memudahkan dalam pengerjaannya. Siswa INTJ memeriksa kembali hasil pengerjaan secara keseluruhan dari awal pengerjaan dalam menyusun strategi sampai pada hasil akhir. Dalam menyimpulkan penyelesaian soal pemecahan masalah siswa INTJ dapat menghubungkannya dengan informasi data yang telah diketahui sebelumnya.

4. Profil Pemecahan Masalah Matematika Kontekstual Siswa SMP Ditinjau dari Kepribadian IntrovertiNtuition-Feeling-Judging (INFJ).

Pada langkah memahami masalah, siswa INFJ dapat memenuhi indikator memahami masalah karena dapat menentukan informasi yang dibutuhkan dengan menghubungkan informasi yang sudah diketahui. Dalam tahap menyusun strategi, siswa INFJ menyusun strategi dengan menghubungkan konsep SPLDV. Siswa INFJ dapat menggunakan strategi yang telah dirancang sebelumnya 'pada soal pemecahan masalah yang diberikan. Siswa INFJ dapat melakukan perhitungan dengan menggunakan konsep/rumus yang sesuai. Dalam proses perhitungannya siswa INFJ menggunakan cara yang berbeda dari siswa dengan kepribadian lainnya. Namun, siswa INFJ tidak dapat menjelaskan secara logis mengenai proses perhitungan dalam melaksanakan rencana penyelesaian masalah karena bersandar pada feeling yang menjelaskan bahwa apa yang menurutnya benar maka itulah yang akan ditulis. Siswa INFJ 
memeriksa kembali hasil yang didapatkan dengan ketentuan yang diberikan. Dalam menyimpulkan penyelesaian soal pemecahan masalah apa yang disimpulkan oleh siswa INFJ hanya berupa gambaran singkat dan belum terinci.

\section{Saran}

1. Berdasarkan hasil penelitian yang telah dijabarkan peneliti, diperoleh adanya sedikit perbedaan dalam pemecahan masalah matematika kontekstual pada siswa dengan masing-masing kepribadian yang diteliti. Sehingga agar pemecahan masalah matematika kontekstual oleh siswa lebih maksimal, sebaiknya guru lebih memperhatikan karakter dan kepribadian siswa. Sehingga dapat menyesuaikan proses pembelajaran dalam kelas, misal dengan mengubah proses pembelajaran dengan mengkombinasikan beberapa cara/model lebih menarik agar tidak hanya siswa yang berkepribadian itu-itu saja yang dapat memahami.

2. Untuk peneliti lain, jika ingin melanjutkan penelitian ini sebaiknya menggunakan subjek dengan kepribadian myer briggs type indicator yang lebih luas lagi agar dapat mengetahui perbedaan pemecahan masalah kontekstual oleh tipe kepribadan lainnya.

3. Penelitian ini hanya menggunakan satu materi yaitu materi SPLDV pada jenjang SMP kelas 8. Oleh karena itu, jika ingin melanjutkan penelitian ini sebaiknya menggunakan materi lain dan memilih jenjang sekolah yang lebih tinggi agar dapat mengetahui kemampuan pemecahan masalah matematika kontekstual pada materi yang lain dengan jenjang sekolah yang berbeda.

\section{DAFTAR PUSTAKA}

Abdurrahman, M. (2010). Pendidikan Bagi Anak Berkesulitan Belajar. Jakarta: Rineka Cipta.

Abid, M. (2018). Kemampuan Berpikir Kritis Siswa Sma Dalam Memecahkan Masalah Turunan Ditinjau Dari Tipe Kepribadian Sensing Dan Intuitive. Mathedunesa, 7(2), 345-347. Dipetik Desember 30, 2020

Anggreini, D., \& Saputra, D. K. (2020). Profile of Skills Students in Resolving Problems Trigonometry Based on. Proc. Internat. Conf. Sci. Engin. 3, hal. 531-536. Tulungagung: STKIP Tulungagung. Dipetik Desember 20, 2020

Barkai, J. (2009). Psychological Types \& Conflict MyersBriggs Type Indicator. Hawai Edu, 5-6. Dipetik Agustus 19, 2020, dari www2.hawaii.edu/ barkai
Briggs-Myers, I., \& Briggs, K.C. (1985). Myers-Briggs Type Indicator (MBTI). Palo Alto, CA: Consulting Psychologists Press.

Dardiri, Y., Supratman, \& Ratnaningsih, N. (2020). Proses Berpikir Divergen Peserta Didik Dalam Memecahkan Masalah Matematika Ditinjau Dari Tipe Kepribadian Myer Briggs. Journal of Authentic Research on Mathematics Education (JARME), 22, 142-157.

Depdikbud. (2014). PERMENDIKBUD No.58 Th. 2014 tentang Kurikulum 2013Sekolah Menengah Pertama/Madrasah Tsanawiyah. Jakarta: Kemendikbud.

Fauzi, A. M., \& Abidin, Z. (2019). Analisis Ketrampilan Berpikir Kritis Tipe Kepribadian ThinkingFeeling Dalam Menyelesaikan Soal PISA. Suska Journal of Mathematics Education, 5(1), 1-8. Dipetik Desember 26, 2020

Hadi, S., \& Novaliyosi. (2019). Timss Indonesia (Trends In International Mathematics and Science Study). Prosiding Seminar Nasional \& Call For Papers (hal. 563). Tasikmalaya: Universitas Siliwangi.

Handican, R., \& Safitri, R. (2017). esalahan Siswa Tipe Kepribadian Thinking dan Feelingdalam Menyelesaikan Masalah Program Linear. Seminar Matematika dan Pendidikan Matematika (hal. PM-614). Yogyakarta: Universitas Negeri Yogyakarta.

Herawaty, D., \& Widada, W. (2018). The Influence of Contextual Learning Models and the Cognitive Conflict to Understand Mathematical Concepts and Problems Solving Abilities. First International Conference on Science, Mathematics, and Education. 218, hal. 6-5. Bengkulu: Atlantis Press. Dipetik Desember 10, 2019

Isroil, A., Budayasa, I., \& Masriyah. (2017). Profil Berpikir Siswa SMP dalam Menyelesaikan Masalah Matematika Ditinjau dari Kemampuan Matematika. Jurnal Review Pembelajaran Matematika (JRPM), 2(2), 94-95. Dipetik 01 10, 2021

Jannah, M. (2016). Analisis Proses Berpikir Kreatif Siswa Dalam Menyelesaikan Masalah Peluang Berdasarkan Tipe Kepribadian Myers Briggs Type Indicator (MBTI). Skripsi. Surabaya: UIN Sunan AMpel.

Jessee, S. A., O'Neill, P., \& Dosch, R. (2006). Matching Student Personality Types and Learning Preferences to Teaching Methodologies. Journal of Dental Education, 70(6), 644.

Jung, C. (1971). Psychological Types (Vol. 6). Princeton, New Jersey: H.G. Barynes, Trans.

Lutfiananda, I. M. (2014). Profil Pemecahan Masalah Open-Ended Siswa Berkepribadian Stj Dan Nfj. 
Mathedunesa, 3(2), 110-111. Dipetik November 28, 2020

Martin, J. (1992). A Comparison of Personality Type and Learning Style of Elementary Education Majors, Math Majors, and Math Professors: Cultures in Conflict. Honors Project, 8-9.

Maya, N. (2018). Analisis Tipe Kepribadian Siswa dan Pengaruhnya terhadap Kemampuan Pemecahan Masalah matematika Menggunakan Model Problem Based Learning. Symmetri, 3(1), 48. Dipetik Desember 15, 2020

Miles, M., Huberman, A., \& Saldana, J. (2014). Qualitative Data Analysis, A Methods Sourcebook, Edition 3. (T. R. Rohidi, Penerj.) USA: Sage Publications.

Moleong, L. (2012). Metodologi Penelitian Kualitatif. Bandung: PT Remaja Rosdakarya.

Mudrika, N. (2011). Myer Briggs Type Indicator. Yogyakarta: UGM.

Myszkowski, N., Storme, M., Davila, A., \& Lubart, T. (2015). Managerial Creative Problem Solving and The Big Five Personality Traits. Journal of Management Development, 34(6), 674-684. Dipetik Januari 10, 2021

Nahdi, D. S. (2019). Keterampilan Matematika di Abad 21. Jurnal Cakrawala Pendas, 5(2), 135-137. Dipetik Desember 5, 2020

Polya, G. (1973). How to Solve it: A new aspect of mathematical method. New Jersey: Princeton University Press.

Prastyo, H. (2020). Kemampuan Matematika Siswa Indonesia Berdasarkan TIMSS. Jurnal Padegogik, 3(2), 111-117.

Puspendik. (2019). Hasil UN 2019. Indonesia: Kemendikbud. Dipetik November 12, 2020, dari https://hasilun.puspendik.kemdikbud.go.id

Rohim, M. F., \& Sari , A. F. (2019). Keterampilan Siswa Memecahkan Masalah Olimpiade Matematika. Jurnal Elemen, 5(1), 80-92.
Setiyaningrum, D. (2019). Analisis Proses Berpikir Siswa SMP dalam Memecahkan Masalah Matematika Berkonteks Ditinjau dari Tipe Kepribadian dalam Pembelajaran dengan Blended Learning. Master Thesis (hal. 237-240). Semarang: Universitas Negeri Semarang.

Sofiani, Y. (2019). Profil Translasi Antar Representasi Siswa Dalam Pemecahan Masalah Matematika Ditinjau dari Tipe Kepribadian. Skripsi (hal. 198201). Surabaya: UIN Sunan Ampel Surabaya.

Subchan, winarni, Mufid, M. S., Fahim, K., \& Syaifudin, W. H. (2018). Buku Guru Matematika untuk SMP/MTs Kelas IX Revisi 2018. Jakarta: Kementrian Pendidikan dan Kebudayaan.

Suherman. (2015). Kreativitas Siswa Dalam Memecahkan Masalah Matematika Materi Pola Bilangan dengan Pendekatan Matematika Realistik (PMR). Al-Jabar Jurnal Pendikan Matematika, 6(1), 81-90.

Tohir, M. (2019). Hasil PISA Indonesia Tahun 2018 Turun Dibanding Tahun 2015. Situbondo: Universitas Ibrahimy. Dipetik 2020 13, November

Tong, D. H., \& Loc, N. P. (2017). Students' Errors In Solving Mathematical Word Problems and Their Ability In Identifying Errors In. European Journal of Education Studies, 3(6), 238-239. doi:10.5281/zenodo.581482

Umami, A. H. (2015). Kemampuan Koneksi Matematika Siswa dalam Pemecahan Masalah Ditinjau dari Gaya Kognitif Reflektif-Impulsif. Skripsi belum dipublikasikan.

Wijaya, E. Y., Sudjimat, D. A., \& Nyoto, A. (2016). Transformasi Pendidikan Abad 21 Sebagai Tuntutan Pengembangan Sumber Daya Manusia Di Era Global. Prosiding Seminar Nasional Pendidikan Matematika (hal. 264). Malang: Universitas Kanjuruhan Malang. 